\title{
Pediatric severe asthma: a case series report and perspectives on anti-lgE treatment
}

Virginia Mirra, Silvia Montella and Francesca Santamaria*

\begin{abstract}
Background: The primary goal of asthma management is to achieve disease control for reducing the risk of future exacerbations and progressive loss of lung function. Asthma not responding to treatment may result in significant morbidity. In many children with uncontrolled symptoms, the diagnosis of asthma may be wrong or adherence to treatment may be poor. It is then crucial to distinguish these cases from the truly "severe therapy-resistant" asthmatics by a proper filtering process. Herein we report on four cases diagnosed as difficult asthma, detail the workup that resulted in the ultimate diagnosis, and provide the process that led to the prescription of omalizumab.

Case presentation: All children had been initially referred because of asthma not responding to long-term treatment with high-dose inhaled steroids, long-acting $\beta_{2}$-agonists and leukotriene receptor antagonists. Definitive diagnosis was severe asthma. Three out four patients were treated with omalizumab, which improved asthma control and patients' quality of life. We reviewed the current literature on the diagnostic approach to the disease and on the comorbidities associated with difficult asthma and presented the perspectives on omalizumab treatment in children and adolescents. Based on the evidence from the literature review, we also proposed an algorithm for the diagnosis of pediatric difficultto-treat and severe asthma.

Conclusions: The management of asthma is becoming much more patient-specific, as more and more is learned about the biology behind the development and progression of asthma. The addition of omalizumab, the first targeted biological treatment approved for asthma, has led to renewed optimism in the management of children and adolescents with atopic severe asthma.
\end{abstract}

Keywords: Severe asthma, Omalizumab, Children, Adolescents, Asthma exacerbations

\section{Background}

Children with poor asthma control have an increased risk of severe exacerbations and progressive loss of lung function, which results in the relevant use of health resources and impaired quality of life (QoL) [1]. Therefore, the primary goal of asthma management at all ages is to achieve disease control [2-4].

According to recent international guidelines, patients with uncontrolled asthma require a prolonged maintenance treatment with high-dose inhaled corticosteroids (ICS) in association with a long-acting $\beta_{2}$-agonist (LABA) plus oral leukotriene receptor antagonist (LTRA) (Table 1) [5].

Nevertheless, in the presence of persistent lack of control, reversible factors such as adherence to treatment or inhalation technique should be first checked for, and diseases that can masquerade as asthma should be promptly excluded. Finally, additional strategies, in particular anti-immunoglobulin E (anti-IgE) treatment (omalizumab), are suggested for patients with moderate or severe allergic asthma that remains uncontrolled in Step 4 [5].

Herein, we reviewed the demographics, clinical presentation and treatment of four patients with uncontrolled severe asthma from our institution in order to explain why we decided to prescribe omalizumab. We also provided a review of the current literature that focuses on recent advances in the diagnosis of pediatric difficult asthma and the associated comorbidities, and summarizes the perspectives on anti-IgE treatment in children and adolescents.

* Correspondence: santamar@unina.it

Department of Translational Medical Sciences, Federico II University, Via

Sergio Pansini 5, 80131 Naples, Italy

(c) The Author(s). 2018 Open Access This article is distributed under the terms of the Creative Commons Attribution 4.0 International License (http://creativecommons.org/licenses/by/4.0/), which permits unrestricted use, distribution, and reproduction in any medium, provided you give appropriate credit to the original author(s) and the source, provide a link to the Creative Commons license, and indicate if changes were made. The Creative Commons Public Domain Dedication waiver (http://creativecommons.org/publicdomain/zero/1.0/) applies to the data made available in this article, unless otherwise stated. 
Table 1 Recommended options for initial controller treatment in children and adults according to GINA Guidelines [5]

\begin{tabular}{llllll}
\hline & Step 1 & Step 2 & Step 3 & Step 4 & Step 5 \\
\hline Preferred choice & - & Low dose ICS & Low dose ICS/LABA & Medium/high dose ICS/LABA & Add anti-IgE \\
Alternative choices & Low dose ICS & LTRA & Medium/high dose ICS & Add tiotropium & Add tiotropium \\
& & Low-dose theophylline & Low dose ICS + LTRA & High dose ICS + LTRA & Add low dose OCS \\
& & Low dose ICS + theophylline & High dose ICS + theophylline & \\
\hline
\end{tabular}

Theophylline is not recommended for children 6-11 years, while tiotropium is not indicated in patients $<18$ years

ICS inhaled corticosteroids, LTRA leukotriene receptor antagonist, LABA long-acting $\beta_{2}$-agonist, anti-lgE anti-immunoglobulin $E$ therapy, OCS oral corticosteroids

\section{Case presentations}

Table 2 summarizes the clinical characteristics and the triggers/comorbidities of the cases at referral to our Institution. Unfortunately, data on psychological factors, sleep apnea, and hyperventilation syndrome were not available in any case. Clinical, lung function and airway inflammation findings at baseline and after 12 months of follow-up are reported in Table 3. In the description of our cases, we used the terminology recommended by the ERS/ATS guidelines on severe asthma [6].

\section{Case 1}

A full-term male had severe preschool wheezing and, since age 3, recurrent, severe asthma exacerbations with frequent hospital admissions. At age 11, severe asthma was diagnosed. Sensitization to multiple inhalant allergens (i.e., house dust mites, dog dander, Graminaceae pollen mix, and Parietaria judaica) and high serum IgE levels $(1548 \mathrm{KU} / \mathrm{l})$ were found. Body mass index (BMI) was within normal range. Combined treatment with increasing doses of ICS (fluticasone, up to $1000 \mu \mathrm{g} /$ day) in association with LABA (salmeterol, $100 \mu \mathrm{g} /$ day) plus LTRA (montelukast, $5 \mathrm{mg} /$ day) has been administered over 2 years. Nevertheless, persistent symptoms and monthly hospital admissions due to asthma exacerbations despite correct inhaler technique and good adherence were reported. Parents refused to perform any test to exclude gastroesophageal reflux (GER) as comorbidity [6]. However, an ex-juvantibus 2-month-course with omeprazole was added to asthma treatment [7], but poor control persisted. Anterior rhinoscopy revealed rhinosinusitis that was treated with nasal steroids for six months [8], but asthma symptoms were unmodified. Treatment with omalizumab was added at age 12 . Reduced hospital admissions for asthma exacerbations, no further need for systemic steroids, and improved QoL score (from 2.0 up to 6.7 out of a maximum of 7 points) were documented over the following months. Unfortunately, after one year of treatment, adherence to omalizumab decreased because of family complaints, and eventually parents withdrew their informed consent and discontinued omalizumab. Currently, by age 17, treatment includes inhaled salmeterol/fluticasone (100 $\mu \mathrm{g} / 500 \mu \mathrm{g} \cdot$ day $^{-1}$, respectively) plus oral montelukast (10 mg/day). Satisfactory symptom control is reported, with no asthma exacerbations.

Table 2 Clinical characteristics of described patients with difficult asthma

\begin{tabular}{|c|c|c|c|c|}
\hline & Case 1 & Case 2 & Case 3 & Case 4 \\
\hline Age at asthma symptoms onset & 3 years & 6 years & 3 years & 4 years \\
\hline \multirow[t]{2}{*}{ History } & $\begin{array}{l}\text { Monthly asthma } \\
\text { exacerbations/ } \\
\text { hospital admissions }\end{array}$ & $\begin{array}{l}\text { Monthly asthma } \\
\text { exacerbations/ } \\
\text { hospital admissions }\end{array}$ & $\begin{array}{l}\text { Monthly asthma } \\
\text { exacerbations/ } \\
\text { hospital admissions }\end{array}$ & $\begin{array}{l}\text { Monthly asthma } \\
\text { exacerbations/ } \\
\text { hospital admissions }\end{array}$ \\
\hline & $\begin{array}{l}\text { Frequent need } \\
\text { of systemic steroids }\end{array}$ & $\begin{array}{l}\text { Frequent need of } \\
\text { systemic steroids }\end{array}$ & $\begin{array}{l}\text { Several ICU admissions } \\
\text { Frequent need of } \\
\text { systemic steroids }\end{array}$ & $\begin{array}{l}\text { Frequent need of } \\
\text { systemic steroids }\end{array}$ \\
\hline Allergen sensitization & $\begin{array}{l}\text { House dust mites, dog } \\
\text { dander, Graminaceae pollen } \\
\text { mix, Parietaria judaica }\end{array}$ & House dust mites & $\begin{array}{l}\text { House dust mites, dog } \\
\text { and cat dander, Alternaria } \\
\text { alternata, Graminaceae } \\
\text { pollen mix, Artemisia vulgaris, } \\
\text { Parietaria judaica, Olea } \\
\text { europaea pollen, cow milk } \\
\text { proteins, egg, peanuts }\end{array}$ & $\begin{array}{l}\text { House dust mites, dog } \\
\text { dander, Graminaceae } \\
\text { pollen mix, Olea europaea } \\
\text { pollen, tomatoes, beans, } \\
\text { shrimps, peas }\end{array}$ \\
\hline Age at referral & 11 years & 10 years & 6 years & 8 years \\
\hline Comorbidity & Rhinosinusitis & GER & Absent & Absent \\
\hline
\end{tabular}

Treatment at referral Fluticasone $(1000 \mu \mathrm{g} / \mathrm{d})+$ salmeterol + montelukast
Fluticasone $(1000 \mu \mathrm{g} / \mathrm{d})+$ Fluticasone $(1000 \mu \mathrm{g} / \mathrm{d})+$ salmeterol + montelukast salmeterol + montelukast
Fluticasone $(1000 \mu \mathrm{g} / \mathrm{d})+$ salmeterol + montelukast 
Table 3 Clinical findings at baseline and after 12 months of follow-up in patients with difficult asthma

\begin{tabular}{|c|c|c|c|c|c|c|c|c|}
\hline & \multicolumn{2}{|l|}{ Case 1} & \multicolumn{2}{|l|}{ Case 2} & \multicolumn{2}{|l|}{ Case 3} & \multicolumn{2}{|l|}{ Case 4} \\
\hline & Baseline & T 12 months & Baseline & T 12 months & Baseline & T 12 months & Baseline & T12 months \\
\hline FVC (\% pred) & 109 & 127 & 95 & 97 & 98 & 95 & 103 & 113 \\
\hline $\mathrm{FEV}_{1}(\%$ pred $)$ & 80 & 78 & 74 & 85 & 67 & 94 & 90 & 85 \\
\hline Post BD $\triangle \mathrm{FEV}_{1}(\%)$ & 3 & NA & 7 & NA & 25 & NA & 12.1 & NA \\
\hline $\mathrm{FEV}_{1} / \mathrm{FVC}(\%)$ & 64 & 87 & 69 & 73 & 67 & 82 & 70 & 66 \\
\hline $\mathrm{FEF}_{25-75}(\%$ pred $)$ & 14 & 61 & 41 & 55 & 25 & 72 & 48 & 46 \\
\hline Post BD $\triangle \mathrm{FEF}_{25-75}(\%)$ & 21 & NA & 8 & NA & 55 & NA & 69 & NA \\
\hline FeNO (ppb) & 54 & 21 & 19 & 7 & 36 & 5 & 116 & NA \\
\hline QoL score & 2.0 & 6.7 & 3.9 & 6.5 & 6.4 & 6.8 & 4.0 & 5.9 \\
\hline c-ACT Score & 17 & 23 & 22 & 25 & 17 & 21 & 12 & 15 \\
\hline Current treatment & \multicolumn{2}{|c|}{$\begin{array}{l}\text { Fluticasone }(500 \mu \mathrm{g} / \mathrm{d})+ \\
\text { salmeterol }+ \text { montelukast }\end{array}$} & \multicolumn{2}{|c|}{$\begin{array}{l}\text { Fluticasone }(100 \mu \mathrm{g} / \mathrm{d})+ \\
\text { salmeterol + omalizumab }\end{array}$} & \multicolumn{2}{|c|}{$\begin{array}{l}\text { Fluticasone }(200 \mu \mathrm{g} / \mathrm{d})+ \\
\text { montelukast }+ \text { omalizumab }\end{array}$} & \multicolumn{2}{|c|}{$\begin{array}{l}\text { Fluticasone }(1000 \mu \mathrm{g} / \mathrm{d})+ \\
\text { salmeterol + montelukast }\end{array}$} \\
\hline
\end{tabular}

$B D$ bronchodilator, $\triangle \%$ predicted changes from the pre-bronchodilator values, FeNO fractional exhaled nitric oxide, Ppb part per billion, QoL Quality of Life defined according to references [14], c-ACT Children Asthma Control Test evaluated according to references [79, 80], NA Not Available

\section{Case 2}

A full-term male, who had a recurrent severe preschool wheezing, at 6 years of age developed exercise-induced asthma. At age 10, severe asthma was diagnosed. High serum IgE levels $(1300 \mathrm{KU} / \mathrm{l})$ and skin prick tests positive to house dust mites were found. Despite a 3-year treatment with progressively increasing doses of inhaled fluticasone (up to $1000 \mu \mathrm{g} /$ day) combined with salmeterol $(100 \mu \mathrm{g} /$ day $)$ and oral montelukast (5 mg/day), monthly hospital admissions with systemic steroids use were reported. At age 13, a 24-h esophageal impedance/ $\mathrm{pH}$ study demonstrated the presence of acid and nonacid GER [7]. Esomeprazole was added to asthma medications, but with an incomplete clinical benefit for respiratory symptoms. Esomeprazole was withdrawn after 3 months, and parents refused to re-test for GER. As respiratory symptoms persisted uncontrolled despite treatment, severe asthma was definitively diagnosed [6]. BMI was within the normal range and anterior rhinoscopy excluded rhinosinusitis. Inhaler technique and adherence were good; thus we considered the anti-IgE treatment option [9]. Subcutaneous omalizumab was started, with fast improvement of both symptoms and QoL score (from 3.9 up to 6.5). Seventeen months later, the dose of ICS had been gradually tapered and oral montelukast definitely discontinued. Currently, at age 14 , treatment includes the combined administration of bimonthly subcutaneous omalizumab and of daily inhaled salmeterol/fluticasone $\left(50 \mu \mathrm{g} / 100 \mu \mathrm{g} \cdot\right.$ day $^{-1}$, respectively). Asthma control is satisfactory and no side effects are reported. Omalizumab has been continuously administered for 2.6 years and is still ongoing.

\section{Case 3}

A full-term male had severe preschool wheezing and, since age 3, recurrent, severe asthma exacerbations with acute respiratory failure that frequently required intensive care unit (ICU) admission. At age 6, sensitization to multiple perennial inhalant (i.e., house dust mites, dog and cat danders, Alternaria alternata, Graminaceae pollen mix, Artemisia vulgaris, Parietaria judaica, and Olea europaea pollen) and food allergens (i.e., egg, milk, and peanut) was diagnosed. Serum IgE levels were 2219 KU/l. Weight and height were appropriate for age and sex. The patient has been treated over 3 years with a combined scheme of high-dose inhaled fluticasone (up to $1000 \mu \mathrm{g} /$ day) plus salmeterol (100 $\mu \mathrm{g} /$ day) and oral montelukast ( $5 \mathrm{mg} /$ day), with correct inhaler technique and good adherence. Despite this, monthly hospital admissions with systemic steroids use were recorded. Rhinosinusitis and GER were excluded on the basis of appropriate testing; thus treatment with omalizumab was started when the patient was 9 years old. At age 11, adherence to treatment is satisfactory, with no side effects. More importantly, reduced hospital admissions for asthma exacerbations, no further need for systemic steroids, and improved QoL score (from 6.4 to 6.8$)$ were reported. Finally, progressive step-down of anti-asthma treatment was started, and at present (by 11.5 years $)$ inhaled fluticasone $(200 \mu \mathrm{g} /$ day $)$ plus bimonthly subcutaneous omalizumab provide good control of symptoms. Omalizumab has been continuously administered for 2.6 years and is still ongoing.

\section{Case 4}

A full-term male had severe preschool wheezing and, since age 4, recurrent, severe asthma exacerbations with frequent hospital admissions. At age 8, multiple perennial inhalants and food sensitization (i.e., house dust mites, dog dander, Graminaceae pollen mix, Olea europaea pollen, tomatoes, beans, shrimps, and peas) and high serum IgE levels (1166 $\mathrm{KU} / \mathrm{l}$ ) were found. The patient has been treated over 5 years with inhaled fluticasone (up to $1000 \mu \mathrm{g} /$ day) in association 
with salmeterol $(100 \mu \mathrm{g} /$ day $)$ and oral montelukast $(5 \mathrm{mg} /$ day). Despite this, monthly hospital admissions with systemic steroids need were recorded. After checking the inhaler technique and adherence to treatment, comorbidities including obesity, rhinosinusitis and GER were excluded. Omalizumab was proposed, but parents refused it. By 13.6 years, despite a treatment including the association of inhaled salmeterol/fluticasone $(100 \mu \mathrm{g} /$ $1000 \mu \mathrm{g} \cdot \mathrm{day}^{-1}$, respectively) plus oral montelukast (10 mg/ day), monthly exacerbations requiring systemic steroids are reported.

\section{Discussion and conclusions}

Most children and adolescents with asthma respond well to inhaled short-acting beta ${ }_{2}$-agonists (SABA) on demand if symptoms are intermittent, or to low dose controller drugs plus as-needed SABA if the risk of exacerbations increases [1]. Nevertheless, a proportion of patients is referred to specialists because this strategy is not working and asthma is persistently uncontrolled [4]. For these children, assessment is primarily aimed at investigating the reasons for poor control. Indeed, when the child is initially referred, before the label of "severe, therapy-resistant asthma" (i.e., not responding to treatment even when factors as exposure to allergens and tobacco smoke have been considered) is assigned, three main categories need to be identified: 1) "not asthma at all", in which response to treatment is suboptimal because the diagnosis is wrong; 2) "asthma plus", when asthma is mild but exacerbated by one or more comorbidities; and 3) "difficult-to-treat asthma", when asthma is uncontrolled because of potentially reversible factors [10].

The reported cases highlight some aspects of the disease process that may expand the diagnosis and improve patients' care. At our institution, the severe asthma program includes a multidisciplinary approach with consultations by gastroenterologists as well as ear, nose and throat experts. Recently, sleep medicine experts joined this multidisciplinary team; thus, unfortunately, sleepdisordered breathing (SDB) could not be excluded at the time of our patients' assessment. Inhalation technique is periodically evaluated by nurses or doctors in each patient. Unfortunately, in Italy an individual prescription database is not available and thus we cannot assess patients' use of medication. In two cases, the filtering process eventually identified GER and rhinosinusitis, but poor control of asthma persisted even after comorbidities were treated. In all subjects, inhaler skills, treatment adherence, and environmental exposure to indoor/outdoor allergens as well as to second- and third-hand smoke were excluded as cause of lack of control. Eventually, three out of four patients started anti-IgE treatment; asthma control was obtained and maintenance drugs were progressively reduced. In the case that refused omalizumab therapy, pulmonary function, clinical features and controller treatment including high-dose ICS were unchanged.

Previous studies have highlighted an association between increasing asthma severity in children and reduced QoL [11-13]. Uncontrolled asthma symptoms not only affect children physically, but can impair them socially, emotionally, and educationally [13]. In line with previous observations, 3 out 4 of our cases had poor QoL, assessed by a standardized questionnaire [14]. It is well known that improving QoL in difficult asthma is not an easy task, despite a variety of treatments aimed at achieving control [12], and much more remains to be done to address the problem. Nevertheless, 2 of our 3 cases showed a remarkable improvement of QoL after one year of treatment with omalizumab.

Reduction in forced expiratory volume in the first second $\left(\mathrm{FEV}_{1}\right)$ is often used to define childhood asthma severity in treatment guidelines and clinical studies $[5,11$, 15]. Nevertheless, children with severe asthma often have a normal $\mathrm{FEV}_{1}$ that does not improve after bronchodilators, indicating that spirometry may be a poor predictor of asthma severity in childhood $[6,16,17]$. Actually, children with a normal $\mathrm{FEV}_{1}$, both before and after $\beta_{2}$-agonist, may show a bronchodilator response in terms of forced expiratory flow between $25 \%$ and $75 \%\left(\mathrm{FEF}_{25-75}\right)$ [18]. However, the utility of $\mathrm{FEF}_{25-75}$ in the assessment or treatment of severe asthma is currently unknown. Interestingly, all the reported cases showed normal or slightly reduced values of $\mathrm{FEV}_{1}$ but severe impairment of $\mathrm{FEF}_{25-75}$. Two cases showed a bronchodilator response in terms of $\mathrm{FEV}_{1}$ (subjects 3 and 4), while 3 patients had a significant increase of $\mathrm{FEF}_{25-75}$ (cases 1, 3 and 4). Unfortunately, we could not provide the results of bronchodilator response during or after the treatment with omalizumab in any case.

Available literature on the diagnostic approach to difficult asthma in children offers a number of reviews which basically summarize the steps needed to fill the gap between a generic diagnosis of "difficult asthma" and more specific labels (i.e., "severe" asthma, "difficult-to-treat" asthma, or even different diagnoses) $[3,5,6,8,10,19-21]$. So far, few original articles and case reports have been published, probably due to the peculiarity of the issue, which makes retrospective discussion of cases easier than the design of a prospective clinical study [4, 22-26]. Available knowledge mainly derives from the experience of specialized centers.

The evaluation of a child referred for uncontrolled asthma should start with a careful history focused on typical respiratory symptoms and on the definition of possible triggers. In the "severe asthma" process, it is crucial for clinicians to maintain a high degree of skepticism about the ultimate diagnosis, particularly in the presence of relevant discrepancies between history, physical features and lung function, as many conditions may be misdiagnosed as asthma. In order to simplify this process, herein we 
propose an algorithm for the diagnosis of difficult-to-treat and severe asthma (Fig. 1). Confirmation of the diagnosis through a detailed clinical and laboratory re-evaluation is important because in $12-50 \%$ of cases assumed to have severe asthma this might not be the correct diagnosis [10]. Several documents have indicated the main steps of the process that should be followed in children with uncontrolled asthma $[3,8,10]$. The translation of these procedures into real life practice may deeply change from one subject to another due to the variability of individual patients' history and clinical features, which will often lead the diagnostic investigations towards the most likely reason for uncontrolled asthma. For children with apparently severe asthma, the first step is to confirm the diagnosis and, before proceeding to broader investigations, to verify that the poor control is not simply determined by poor adherence to treatment, inadequate inhaler skills and/or environmental exposure to triggers. A nurse-led assessment, including a home visit, despite not being applicable in all settings, may be useful for identifying potentially modifiable factors in uncontrolled pediatric asthma [27].

A number of comorbidities have been increasingly recognized as factors that may impact asthma clinical expression and control in childhood [10, 28]. Children with uncontrolled disease should be investigated for GER, rhinosinusitis, dysfunctional breathing and/or vocal cord dysfunction, obstructive sleep apnea, obesity, psychological factors, smoke exposure, hormonal influences, and ongoing drugs $[3,6,8,20]$. Indeed, the exact role played by comorbidities in pediatric asthma control is still debated [28]. The most impressive example is GER. Several pediatric documents recommend assessing for GER because reflux may be a contributing factor to problematic or difficult asthma $[7,29]$. Nevertheless, GER treatment might not be effective for severe asthma [30, 31], as confirmed by current cases 1 and 2. There is an established evidence that chronic rhinosinusitis is associated with more severe asthma in children
[32-34]. Therefore, examination of upper airways and ad hoc treatment if rhinosinusitis is evident are recommended in children with severe asthma [3, 8, 35]. However, intranasal steroids for rhinitis resulted in a small reduction of asthma risk in school-aged children [36], and actual placebo-controlled studies on the effect of treatment of rhinosinusitis on asthma control in children are lacking [10, 37].

Dysfunctional breathing, including hyperventilation and vocal cord dysfunction, is associated with poorer asthma control in children $[8,10,38,39]$. Unfortunately, there is scarce literature on the effect of its treatment on the control of severe asthma in children [40]. SDB ranging from primary snoring to obstructive sleep apnea syndrome is very common in children [41], and an increased prevalence of SDB together with increasing asthma severity has been reported [42]. Interestingly, GER may also be worsened by recurrent episodes of upper airway obstruction associated with SDB, and this may further trigger bronchial obstruction. Asthma guidelines recommend the assessment of SDB through nocturnal polysomnography in poorly controlled asthmatics, particularly if they are also obese [5]. There are no studies examining whether pediatric asthma improves after SDB has been treated, for example, with nasal steroids, adenotonsillectomy, continuous positive airway pressure or weight reduction if the child is also obese [43]. The parallel increase in obesity and asthma suggests that the two conditions are linked and that they can aggravate each other [44, 45], even though the exact mechanisms that underlie this association remain unclear [46]. Indeed, other coexisting comorbidities such as SDB or GER may play a confounding role in the development of the interactions between obesity and the airways [47, 48]. Obesity is associated with increased markers of inflammation in serum and adipose tissue and yet decreased airway inflammation in obese people with asthma [49]. Several interventions, including behavioral and 
weight reduction programs or bariatric surgery, may result in improved asthma control, quality of life and lung function in adult obese asthmatics [50]. Although reports of adolescent bariatric surgery demonstrate a significant body weight decrease, this approach is not widely available and there are no published reports on its effect on pediatric severe asthma control [51]. Finally, although it is still unclear whether food allergy is causative or shares a common pathway with difficult asthma, it might explain the loss of asthma control at least in some children and thus be considered as a comorbid condition $[10,16,52]$.

In conclusion, establishing the impact of comorbidities on asthma control may be cumbersome, and an ex-juvantibus treatment is sometimes necessary to assess their role. Comorbid conditions can also worsen each other, and symptoms arising from some of them may mimic asthma [6]. Although the ability to improve pediatric severe asthma by treating comorbidities remains unconfirmed, they should be treated appropriately [9].

The vast majority of asthmatic children exhibit a mild or at most a moderate disease that can be fully controlled with low-to-medium dose ICS associated or not with other controllers $[5,6]$. However, a subset of asthmatics remains difficult-to-treat $[5,6]$. With the advent of biologics, these severe steroid-dependent asthmatics have alternative options for treatment, as steroid-related adverse events are common in severe asthma [53]. Omalizumab, an anti-IgE monoclonal antibody, is the only biologic therapy recommended in children with moderate-to-severe asthma by the recent guidelines $[5,6]$. In Italy, this treatment is fully covered by the National Health System. Therefore, there is no influence by any funding on treatment decisions. It was approved by the US (Food and Drug Administration) in 2003 and by the European Union (European Medicines Agency) in 2005 as an add-on treatment for patients aged $>12$ years with severe persistent allergic asthma and who have a positive skin test or in-vitro reactivity to a perennial aeroallergen, $\mathrm{FEV}_{1}<80 \%$ predicted, frequent daytime symptoms or nighttime awakenings, and multiple documented severe asthma exacerbations despite daily ICS plus a LABA [54, 55]. In 2009, it also received approval in Europe for treating patients aged 6-12 years. Figure 2 illustrates current indications for treatment with omalizumab in children and adolescents with severe asthma.

IgE antibodies, $\mathrm{Th}_{2}$-derived cytokines and eosinophils play a major role in the development of chronic airway inflammation in asthmatic subjects [56]. Once released from plasma cells, IgE binds principally to the highaffinity IgE receptor (FcERI) on mast cells, triggering

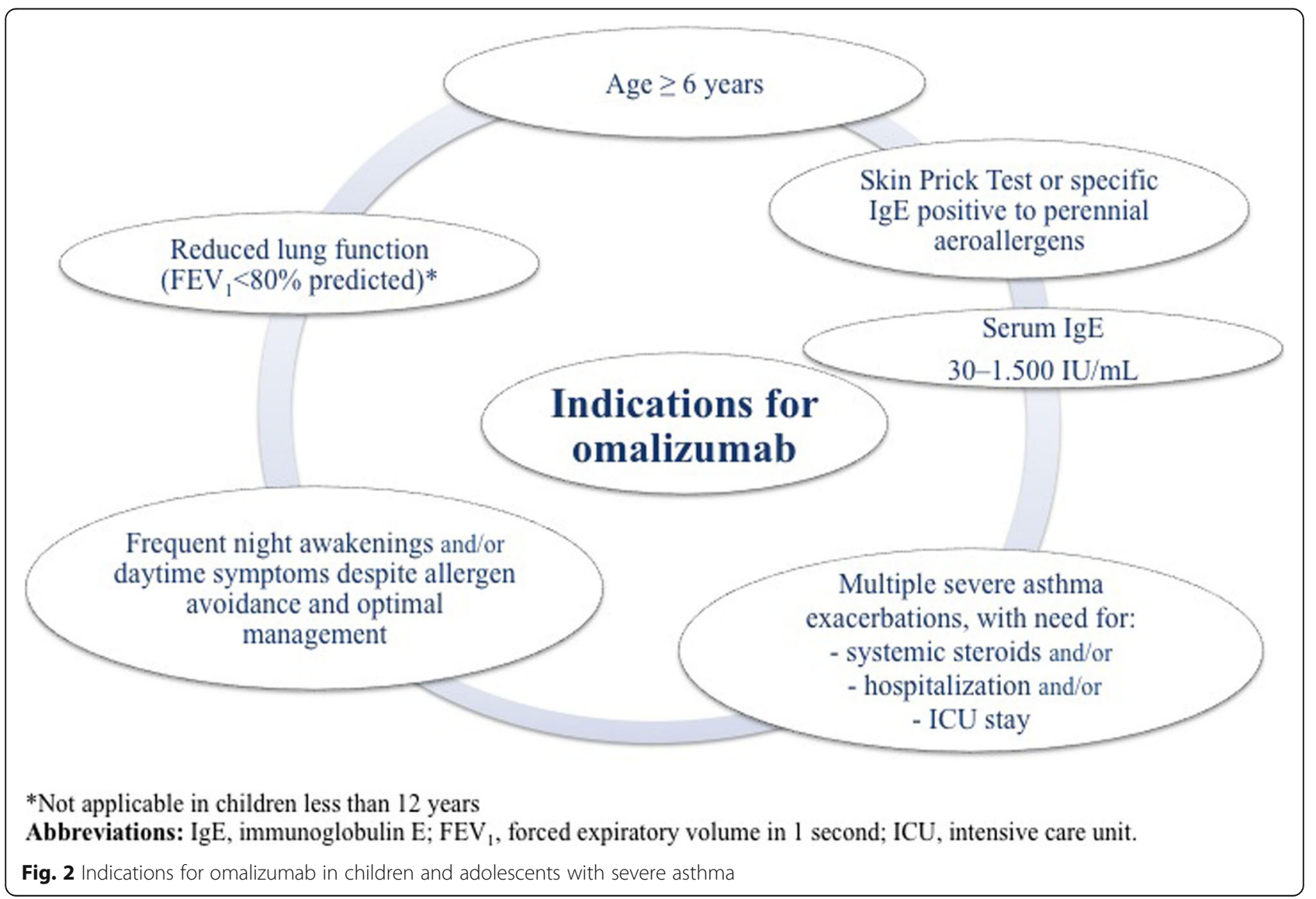


different effector responses, including the release of mediators leading to allergic inflammatory reactions [56]. The activation of the allergic cascade by IgE, under constant allergen stimulation, leads to the establishment of chronic allergic inflammation in the airways of asthmatic patients, with IgE being a key element of the vicious circle that maintains it. Cytokines produced during the late phase and subsequent chronic inflammation stage have been directly associated with the induction of airway remodelling, indirectly implicating $\operatorname{IgE}$ in the process [56]. At present, omalizumab is the only commercially available recombinant humanized anti-IgE monoclonal antibody that specifically binds serum free $\mathrm{IgE}$ at its $\mathrm{CH}_{3}$ domain, in the proximity of the binding site for FceRI, thus preventing IgE from interacting with its receptor on mast cells, basophils, antigen-presenting cells and other inflammatory cells [57]. The rapid reduction of free IgE levels leads to a downregulation of the FceRI expression on inflammatory cells and an interruption of the allergic cascade, which results in the reduction of peripheral and bronchial tissue eosinophilia and of levels of granulocyte macrophage colony stimulating factor, interleukin (IL)-2, IL-4, IL-5, and IL-13 [58]. Moreover, basophils have a relevant role in the initiation and progression of allergic inflammation, suggesting that they may represent a viable therapeutic target. Indeed, in children with severe asthma, it has been reported that omalizumab therapy is associated with a significant reduction in circulating basophil numbers, a finding that is concurrent with improved clinical outcomes [59]. This finding supports a mechanistic link between IgE levels and circulating basophil populations, and may provide new insights into one mechanism by which omalizumab improves asthma symptoms.

Several clinical controlled and real-life studies of adults with severe, inadequately controlled allergic asthma have demonstrated the efficacy and safety of omalizumab in reducing asthma-related symptoms, corticosteroid use, exacerbation rates, and healthcare resource utilization, and in improving QoL and lung function [60-63]. Fewer studies have been published in children. In two doubleblind, randomized, placebo-controlled trials (RCTs) of children aged 6 to 12 years with moderate-to-severe allergic asthma, treatment with omalizumab reduced the requirement for ICS and protected against disease exacerbations, but there was little change in asthma symptom scores or spirometry $[9,64]$. These findings were confirmed and extended in older children [65-67].

The results of the ICATA study, a multicenter RCT of 419 inner-city children, adolescents and young adults with persistent allergic asthma, showed that, compared to placebo, omalizumab reduces the number of days with asthma symptoms and the proportion of participants with at least one exacerbation by approximately $25 \%$ and $19 \%$, respectively $(p<0.001)$, thus reducing the need for asthmatic symptom controllers [68]. Another multicenter RCT of inner-city children and adolescents showed that the addition of omalizumab to ongoing guidelines-based care before patients return to school reduces fall asthma exacerbations (odds ratio, 0.48), particularly in subjects with a recent exacerbation [69]. Moreover, in a real-life study of 104 children and adolescents with severe allergic refractory asthma followed over 1 year, treatment with omalizumab resulted in good asthma control in $67 \%$ of the cases $(p<0.001)$, while $\mathrm{FEV}_{1}$ improved by $4.9 \%(p=0.02)$ and exacerbation rates and healthcare utilisation decreased approximately by $30 \%(p<0.001)$ [70]. The same authors also showed that, after two years of treatment, exacerbation rate and healthcare utilisation were further decreased by $83 \%$ and $100 \%$, respectively, while level of asthma control, steroid use and lung function remained unchanged [71].

A systematic review of pediatric RCTs pooled the data of 1381 children and adolescents with moderateto-severe allergic asthma in order to establish the efficacy of omalizumab as an add-on therapy [72]. During the stable-steroid phase, omalizumab decreased the number of patients with at least one exacerbation (risk ratio, $0.69 ; p<0.001$ ), the mean number of asthma exacerbations per patient (risk ratio, $0.35 ; p<0.001$ ), and the asthma symptom score (mean difference, $0.12 ; p=0.005$ ) when compared to placebo. During the steroid reduction phase, omalizumab further reduced the number of patients with at least one exacerbation (risk ratio, $0.48 ; p<0.001$ ) and the mean number of asthma exacerbations per patient (mean difference, $0.12 ; p<0.05$ ).

Given the cost of omalizumab, many authors have argued for the importance of identifying specific asthma populations who will have significant benefit from it [68, 73, 74]. In the ICATA study, baseline predictors of good response to treatment were sensitization and exposure to cockroach allergen, sensitization to house dust mite allergens, a serum IgE level of more than $100 \mathrm{IU}$ per milliliter, a BMI of 25 or more, and a history of at least one unscheduled medical visit in the previous year [68].

Several studies have assessed the long-term safety of omalizumab in children and adults. A pooled analysis of 67 RCTs conducted over 2 decades on 4254 children and adults treated with omalizumab showed no association between omalizumab treatment and risk of malignancy [75]. In an RCT evaluating 225 school-aged children, omalizumab was well tolerated, there were no serious adverse events, and the frequency and types of all adverse events were similar to the placebo group [9]. These results have been further confirmed by a recent systematic review of RCTs that concluded that treatment with omalizumab does not result in increased risk of malignancy or hypersensitivity reactions [72]. 
While the rationale for long-term treatment with omalizumab is supported by pharmacokinetic-pharmacodynamic models [76], the duration of treatment is still under discussion. Results from published studies suggest that omalizumab should be continued for $>1$ year [77, 78]. In a retrospective study of adults and children with uncontrolled severe asthma treated with omalizumab, the response to treatment was 'excellent' in $52.5 \%$ of patients, particularly in the subgroup of children aged 6 to 11 years [77]. After the discontinuation of treatment, loss of asthma control was documented in $69.2 \%$ of the patients who had received omalizumab for $<1$ year, $59.1 \%$ of the subjects treated for $1-2$ years, and $46.1 \%$ of the cases treated for $>2$ years. Time to loss of control was shorter in younger children and longer in patients with an 'excellent' response compared with patients with a 'good' response. No early loss of control (within 6 months) was observed among patients with $>3.5$ years of continuous treatment with omalizumab. Finally, 20\% of patients in whom omalizumab was represcribed because of loss of control did not respond to the treatment anymore [77]. Despite these encouraging findings, the impact of omalizumab on the natural history of severe asthma in children deserves to be further investigated by long-term studies that will also define the criteria and timing for discontinuing the treatment.

It is well known that asthma pharmacotherapy is effective in controlling symptoms and bronchial inflammation, but cannot affect the underlying immune response, thus leading to the possibility of symptom reappearance after its discontinuation [79]. In this scenario, allergen-specific immunotherapy (AIT) has been proposed as the only therapeutic method that can modulate the underlying immune pathophysiology in allergic asthma [80].

AIT is currently indicated in children and adults with mild-moderate allergic asthma that is completely or partially controlled by pharmacotherapy and with the evidence of a clear relationship between symptoms and exposure to a specific allergen [81-84]. However, according to recent guidelines, the efficacy of AIT in asthmatic subjects is limited, and its potential benefits must be weighed against the risk of side effects and the inconvenience and costs of the prolonged therapy [5]. Moreover, severe or uncontrolled asthma (regardless of its severity) is a major independent risk factor for non-fatal or even fatal adverse reactions, thus representing a contraindication for AIT [85-87]. Finally, children with severe asthma are often sensitized to multiple allergens, thus making AIT prescription even more complicated [88].

In subjects with uncontrolled and/or severe allergic asthma, a combination of omalizumab and AIT has been proposed [88]. Surprisingly, only a few studies have addressed this issue [89-92]. However, pre-treatment with omalizumab seems to improve the efficacy and tolerability of subcutaneous AIT in children and adults with severe allergic asthma both during omalizumab treatment and after its discontinuation [89, 91, 92]. Omalizumab has also been successfully used as a supplementary treatment to AIT in order to improve asthma control in children $\geq 6$ years with severe persistent allergic asthma [90]. Given the scarcity of studies on AIT plus omalizumab in children with severe allergic asthma, further research is warranted to assess risks and benefits of the combined treatment.

Children with severe asthma require a detailed and individualized approach including re-assessment for differential diagnoses, comorbidities and contributory factors, environmental triggers, lung function and inflammation, adherence and response to therapy, and QoL. Treatment of pediatric severe asthma still relies on the maximal optimal use of corticosteroids, bronchodilators and other controllers recommended for moderate-to-severe disease. However, the management of asthma is becoming much more patientspecific, as more and more is learned about the biology behind the development and progression of asthma.

In the current paper, we described the characteristics of four children with severe asthma in whom omalizumab was prescribed. A review of the relevant literature on the topic was also performed. Finally, we provided an algorithm for the diagnosis of difficult-to-treat and severe asthma in children and adolescents, based on the evidence from the literature review. As all algorithms, it is not meant to replace clinical judgment, but it should drive physicians to adopt a systematic approach towards difficult and severe asthma and provide a useful guide to the clinician.

The addition of omalizumab, the first targeted biological treatment approved for asthma, has led to renewed optimism of outcome improvements in patients with allergic severe asthma. As severe asthma is a heterogeneous condition consisting of different phenotypes, the future of asthma management will likely involve phenotypic and potentially even genotypic characterization in selected cases in order to determine appropriate therapy and thus to provide the highest possible benefit, especially if specific responder phenotypes can be identified and selected for this highly specific treatment.

\section{Abbreviations \\ anti-lgE: Anti-immunoglobulin E; BMI: Body mass index; FceRI: IgE receptor; $\mathrm{FEF}_{25-75}$ : Forced expiratory flow between 25\% and 75\%; FEV expiratory volume in the first second; GER: Gastroesophageal reflux; ICS: Inhaled corticosteroids; ICU: Intensive care unit; IL: Interleukin; LABA: Long-acting $\beta_{2}$-agonist; LTRA: Oral leukotriene receptor antagonist; QoL: Quality of life; RCTs: Randomized controlled trials; SABA: Short-acting $\beta_{2}$-agonists; SDB: Sleep-disordered breathing}

\section{Acknowledgements}

The authors gratefully thank Dr. Marco Maglione for his contribution in the clinical assessment of the described cases. Medical writing assistance was provided by Stephen Walters on behalf of City Hills Proofreading.

Funding

No funding was secured for this study. 


\section{Availability of data and materials}

All relevant data and materials are published in the manuscript

\section{Authors' contributions}

VM, SM and FS, authors of the current manuscript, declare that they have participated sufficiently in the work to take public responsibility for appropriate portions of the content. VM and SM carried out the initial investigations, drafted the initial manuscript, revised the manuscript, and approved the final manuscript as submitted. FS conceptualized and designed the study, and critically reviewed and approved the final manuscript as submitted. All authors read and approved the final manuscript.

\section{Ethics approval and consent to participate}

This study was approved by the ethics committee "Carlo Romano", Federico II University, Naples, Italy. Children's parents/legal guardians gave informed written consent to participate. The description of our cases adheres to the CARE standards of reporting checklist.

\section{Consent for publication}

Children's parents/legal guardians provided informed written consent for the case report to be published.

\section{Competing interests}

The authors declare that they have no competing interests to disclose. Authors have no financial relationships relevant to this article to disclose.

\section{Publisher's Note}

Springer Nature remains neutral with regard to jurisdictional claims in published maps and institutional affiliations.

\section{Received: 24 May 2016 Accepted: 29 January 2018}

Published online: 21 February 2018

\section{References}

1. O'Byrne PM, Pedersen S, Schatz M, Thoren A, Ekholm E, Carlsson LG, et al. The poorly explored impact of uncontrolled asthma. Chest. 2013;143:511-3.

2. National Asthma Education and Prevention Program. Expert panel report 3 (EPR-3): guidelines for the diagnosis and Management of Asthma-Summary Report 2007. J Allergy Clin Immunol. 2007;120:S94-8.

3. Hedlin G. Management of severe asthma in childhood-state of the art and novel perspectives. Pediatr Allergy Immunol. 2014;25:111-21.

4. Konradsen JR, Nordlund B, Lidegran M, Pedroletti C, Grönlund H, van Hage $M$, et al. Problematic severe asthma: a proposed approach to identifying children who are severely resistant to therapy. Pediatr Allergy Immunol. 2011;22:9-18.

5. Global Initiative for Asthma Report. Global strategy for asthma management and prevention (updated 2016). https://www.ginasthma. org. Accessed 07 June 2017.

6. Chung KF, Wenzel SE, Brozek JL, Bush A, Castro M, Sterk PJ, et al. International ERS/ATS guidelines on definition, evaluation and treatment of severe asthma. Eur Respir J. 2014;43:343-53.

7. Vandenplas Y, Rudolph CD, Di Lorenzo C, Hassall E, Liptak G, Mazur L, et al. Pediatric gastroesophageal reflux clinical practice guidelines: joint recommendations of the north American Society for Pediatric Gastroenterology, Hepatology, and nutrition (NASPGHAN) and the European Society for Pediatric Gastroenterology, Hepatology, and nutrition (ESPGHAN). J Pediatr Gastroenterol Nutr. 2009;49:498-507.

8. Lødrup Carlsen KC, Hedlin G, Bush A, Wennergren G, de Benedictis FM, De Jongste $\mathrm{JC}$, et al. Assessment of problematic severe asthma in children. Eur Respir J. 2011;37:432-40.

9. Milgrom H, Berger W, Nayak A, Gupta N, Pollard S, McAlary M, et al. Treatment of childhood asthma with anti-immunoglobulin E antibody (omalizumab). Pediatrics. 2001;108:E36.

10. Bush A, Saglani S. Management of severe asthma in children. Lancet. 2010;376:814-5.

11. Lang A, Mowinckel P, Sachs-Olsen C, Riiser A, Lunde J, Carlsen KH, et al. Asthma severity in childhood, untangling clinical phenotypes. Pediatr Allergy Immunol. 2010;21:945-53.

12. Nordlund B, Konradsen JR, Pedroletti C, Kull I, Hedlin G. The clinical benefit of evaluating health-related quality-of-life in children with problematic severe asthma. Acta Paediatr. 2011;100:1454-60.
13. Dean BB, Calimlim BC, Sacco P, Aguilar D, Maykut R, Tinkelman D. Uncontrolled asthma: assessing quality of life and productivity of children and their caregivers using a cross-sectional internet-based survey. Health Qual Life Outcomes. 2010;8:6.

14. Juniper EF, Guyatt GH, Feeny DH, Ferrie PJ, Griffith LE, Townsend M. Measuring quality of life in children with asthma. Qual Life Res. 1996:5:35-46.

15. British Thoracic Society. Scottish Intercollegiate Guidelines Network. British guideline on the management of asthma, 2014. https://www.brit-thoracic.org. uk/guidelines-and-quality-standards/asthma-guideline. Accessed 13 Apr 2016.

16. Montella S, Baraldi E, Cazzato S, Aralla R, Berardi M, Brunetti LM, et al. Severe asthma features in children: a case-control online survey. Ital J Pediatr. 2016;42:9.

17. Fitzpatrick AM, Gaston BM, Erzurum SC, Teague WG, National Institutes of Health/National Heart, Lung, and Blood Institute Severe Asthma Research Program. Features of severe asthma in school-age children: Atopy and increased exhaled nitric oxide. J Allergy Clin Immunol. 2006;1 18:1218-25.

18. Simon MR, Chinchilli VM, Phillips BR, Sorkness CA, Lemanske RF Jr, Szefler SJ, et al. Forced expiratory flow between $25 \%$ and $75 \%$ of vital capacity and FEV1/forced vital capacity ratio in relation to clinical and physiological parameters in asthmatic children with normal FEV1 values. J Allergy Clin Immunol. 2010;126:527-34.

19. Hedlin G, Bush A, Lødrup Carlsen K, Wennergren G, De Benedictis FM, Melén $E$, et al. Problematic severe asthma in children, not one problem but many: a GA2LEN initiative. Eur Respir J. 2010;36:196-201.

20. Fitzpatrick AM, Teague WG. Severe asthma in children: insights from the National Heart, Lung, and Blood Institute's severe asthma research program Pediatr Allergy Immunol Pulmonol. 2010;23:131-8.

21. Konradsen JR, Caffrey Osvald E, Hedlin G. Update on the current methods for the diagnosis and treatment of severe childhood asthma. Expert Rev Respir Med. 2015;9:769-77.

22. Lang AM, Konradsen J, Carlsen KH, Sachs-Olsen C, Mowinckel P, Hedlin G, et al. Identifying problematic severe asthma in the individual child—does lung function matter? Acta Paediatr. 2010;99:404-10.

23. Rao DR, Gaffin JM, Baxi SN, Sheehan WJ, Hoffman EB, Phipatanakul WJ. The utility of forced expiratory flow between $25 \%$ and $75 \%$ of vital capacity in predicting childhood asthma morbidity and severity. Asthma. 2012;49:586-92.

24. Eid N, Yandell B, Howell L, Eddy M, Sheikh S. Can peak expiratory flow predict airflow obstruction in children with asthma? Pediatrics. 2000;105:354-8.

25. Cicutto LC, Chapman KR, Chamberlain D, Downey GP. Difficult asthma: consider all of the possibilities. Can Respir J. 2000;7:415-8.

26. Wener RR, Bel EH. Severe refractory asthma: an update. Eur Respir Rev. 2013;22:227-35

27. Bracken $M$, Fleming $L$, Hall $P$, et al. The importance of nurse-led home visits in the assessment of children with problematic asthma. Arch Dis Child. 2009:94:780-4.

28. De Groot EP, Kreggemeijer WJ, Brand PL. Getting the basics right resolves most cases of uncontrolled and problematic asthma. Acta Paediatr. 2015;104:916-21.

29. Grimaldi-Bensouda L, Zureik M, Aubier M, Humbert M, Levy J, Benichou J, et al. Does omalizumab make a difference to the real-life treatment of asthma exacerbations? Results from a large cohort of patients with severe uncontrolled asthma. Chest. 2013;143:398-405.

30. American Lung Association Asthma Clinical Research Centers, Mastronarde JG, Anthonisen NR, Castro M, Holbrook JT, Leone FT, et al. Efficacy of esomeprazole for treatment of poorly controlled asthma. N Engl J Med. 2009:360:1487-9.

31. Writing Committee for the American Lung Association Asthma Clinical Research Centers, Holbrook JT, Wise RA, Gold BD, Blake K, Brown ED, et al. Lansoprazole for children with poorly controlled asthma: a randomized controlled trial. JAMA 2012;307:373-381.

32. Wright AL, Holberg CJ, Martinez FD, Halonen M, Morgan W, Taussig LM. Epidemiology of physician-diagnosed allergic rhinitis in childhood. Pediatrics. 1994;94:895-901.

33. De Groot EP, Nijkamp A, Duiverman EJ, Brand PL. Allergic rhinitis is associated with poor asthma control in children with asthma. Thorax. 2012;67:582-7.

34. Rotiroti G, Roberts G, Scadding GK. Rhinitis in children: common clinical presentations and differential diagnoses. Pediatr Allergy Immunol. 2015;26:103-10.

35. Bousquet J, Khaltaev N, Cruz AA, Denburg J, Fokkens WJ, Togias A, et al. Allergic rhinitis and its impact on asthma (ARIA). 2008 update (in collaboration with the World Health Organization, GA(2)LEN and AllerGen). Allergy. 2008;63:S8-160. 
36. Deliu M, Belgrave D, Simpson A, Murray CS, Kerry G, Custovic A. Impact of rhinitis on asthma severity in school-age children. Allergy. 2014;69:1515-21.

37. Brozek JL, Bousquet J, Baena-Cagnani CE, Bonini S, Canonica GW, Casale TB, et al. Allergic rhinitis and its impact on asthma (ARIA) guidelines: 2010 revision. J Allergy Clin Immunol. 2010;126:466-76.

38. Weinberger M, Abu-Hasan M. Pseudo-asthma: when cough, wheezing, and dyspnea are not asthma. Pediatrics. 2007;120:855-64.

39. De Groot EP, Duiverman EJ, Brand PL. Dysfunctional breathing in children with asthma: a rare but relevant comorbidity. Eur Respir J. 2013;41:1068-73.

40. Barker NJ, Jones M, O'Connell NE, Everard ML. Breathing exercises for dysfunctional breathing/hyperventilation syndrome in children. Cochrane Database Syst Rev. 2013;12:CD010376.

41. Section on Pediatric Pulmonology, Subcommittee on Obstructive Sleep Apnea Syndrome, American Academy of Pediatrics. Clinical practice guideline: diagnosis and management of childhood obstructive sleep apnea syndrome. Pediatrics. 2002;109:704-12.

42. Goldstein NA, Aronin C, Kantrowitz B, Hershcopf R, Fishkin S, Lee H, Weaver $D E$, et al. The prevalence of sleep-disordered breathing in children with asthma and its behavioral effects. Pediatr Pulmonol. 2015;50:1128-36.

43. Ross KR, Storfer-Isser A, Hart MA, Kibler AM, Rueschman M, Rosen CL, et al. Sleep-disordered breathing is associated with asthma severity in children. J Pediatr. 2012;160:736-42.

44. Santamaria F, Montella S, Greco L, Valerio G, Franzese A, Maniscalco M, et al. Obesity duration is associated to pulmonary function impairment in obese subjects. Obesity (Silver Spring). 2011;19:1623-8.

45. Sivapalan P, Diamant Z, Ulrik CS. Obesity and asthma: current knowledge and future needs. Curr Opin Pulm Med. 2015;21:80-5.

46. Rasmussen F, Hancox RJ. Mechanisms of obesity in asthma. Curr Opin Allergy Clin Immunol. 2014;14:35-43.

47. Santamaria F, Montella S, Pietrobelli A. Obesity and pulmonary disease: unanswered questions. Obes Rev. 2012;13:822-33.

48. Lang JE, Hossain J, Holbrook JT, Teague WG, Gold BD, Wise RA, et al. Gastrooesophageal reflux and worse asthma control in obese children: a case of symptom misattribution? Thorax. 2016;71:238-46.

49. Santamaria F, Montella S, De Stefano S, Sperli F, Barbarano F, Valerio G. Relationship between exhaled nitric oxide and body mass index in children and adolescents. J Allergy Clin Immunol. 2005;116:1163-4.

50. Van Huisstede A, Rudolphus A, Castro Cabezas M, Biter LU, van de Geijn GJ, Taube C, et al. Effect of bariatric surgery on asthma control, lung function and bronchial and systemic inflammation in morbidly obese subjects with asthma. Thorax. 2015;70:659-67.

51. Katzmarzyk PT, Bouchard C. Where is the beef? Waist circumference is more highly correlated with $\mathrm{BMI}$ and total body fat than with abdominal visceral fat in children. Int J Obes. 2014;38:753-4.

52. De Groot EP, Duiverman EJ, Brand PL. Comorbidities of asthma during childhood: possibly important, yet poorly studied. Eur Respir J. 2010;36:671-8

53. Sweeney J, Patterson CC, Menzies-Gow A, Niven RM, Mansur AH, Bucknall C, et al. Comorbidity in severe asthma requiring systemic corticosteroid therapy: cross-sectional data from the optimum patient care research database and the British thoracic difficult asthma registry. Thorax. 2016; https://doi.org/10.1136/thoraxjnl-2015-207630.

54. Federal Drug Administration Advisory for Omalizumab. Available at: https:// wayback.archive-it.org/7993/20170111075347/. http://www.fda.gov/Drugs/ DevelopmentApprovalProcess/HowDrugsareDevelopedandApproved/ ApprovalApplications/TherapeuticBiologicApplications/default.htm. Accessed 4 Feb 2018.

55. European Medicines Agency: assessment report for Xolair. Available at: http://www.ema.europa.eu/ema/index.jsp?curl=pages/medicines/human/ medicines/000606/human_med_001162.jsp\&mid=WC0b01ac058001d124. Accessed 7 June 2017

56. Chung KF. Targeting the interleukin pathway in the treatment of asthma. Lancet. 2015;386:1086-96.

57. Jensen RK, Plum M, Tjerrild L, Jakob T, Spillner E, Andersen GR. Structure of the omalizumab Fab. Acta Crystallogr F Struct Biol Commun. 2015;71:419-26.

58. Holgate $S$, Smith $N$, Massanari M, Jimenez P. Effects of omalizumab on markers of inflammation in patients with allergic asthma. Allergy. 2009;64:1728-36.

59. Hill DA, Siracusa MC, Ruymann KR, Tait Wojno ED, Artis D, Spergel JM. Omalizumab therapy is associated with reduced circulating basophil populations in asthmatic children. Allergy. 2014;69:674-7.

60. Humbert M, Beasley R, Ayres J, Slavin R, Hébert J, Bousquet J, et al. Benefits of omalizumab as add-on therapy in patients with severe persistent asthma who are inadequately controlled despite best available therapy (GINA 2002 step 4 treatment): INNOVATE. Allergy. 2005;60:309-16.

61. Normansell R, Walker S, Milan SJ, Walters EH, Nair P. Omalizumab for asthma in adults and children. Cochrane Database Syst Rev. 2014;1:CD003559.

62. Lai T, Wang S, Xu Z, Zhang C, Zhao Y, Hu Y, Cao C, et al. Long-term efficacy and safety of omalizumab in patients with persistent uncontrolled allergic asthma: a systematic review and meta-analysis. Sci Rep. 2015;5:8191.

63. Abraham I, Alhossan A, Lee CS, Kutbi H, MacDonald K. "real-life" effectiveness studies of omalizumab in adult patients with severe allergic asthma: systematic review. Allergy. 2015; https://doi.org/10.1111/all.12815.

64. Lanier B, Bridges T, Kulus M, Taylor AF, Berhane I, Vidaurre CF. Omalizumab for the treatment of exacerbations in children with inadequately controlled allergic (IgE-mediated) asthma. J Allergy Clin Immunol. 2009;124:1210-6.

65. Solèr M, Matz J, Townley R, Buhl R, O'Brien J, Fox H, et al. The anti-lgE antibody omalizumab reduces exacerbations and steroid requirement in allergic asthmatics. Eur Respir J. 2001;18:254-61.

66. Holgate ST. Cytokine and anti-cytokine therapy for the treatment of asthma and allergic disease. Cytokine. 2004;28:152-7.

67. Odajima H, Ebisawa M, Nagakura T, Fujisawa T, Akasawa A, Ito K, et al. Omalizumab in Japanese children with severe allergic asthma uncontrolled with standard therapy. Allergol Int. 2015;64:364-70.

68. Busse WW, Morgan WJ, Gergen PJ, Mitchell HE, Gern JE, Liu AH, et al. Randomized trial of omalizumab (anti-lgE) for asthma in inner-city children. N Engl J Med. 2011;364:1005-15.

69. Teach SJ, Gill MA, Togias A, Sorkness CA, Arbes SJ Jr, Calatroni A, et al. Preseasonal treatment with either omalizumab or an inhaled corticosteroid boost to prevent fall asthma exacerbations. J Allergy Clin Immunol. 2015; 136:1476-85.

70. Deschildre A, Marguet C, Salleron J, Pin I, Rittié JL, Derelle J, et al. Add-on omalizumab in children with severe allergic asthma: a 1-year real life survey. Eur Respir J. 2013;42:1224-33.

71. Deschildre A, Marguet C, Langlois C, Pin I, Rittié JL, Derelle J, et al. Real-life long-term omalizumab therapy in children with severe allergic asthma. Eur Respir J. 2015:46:856-9.

72. Rodrigo GJ, Neffen $H$. Systematic review on the use of omalizumab for the treatment of asthmatic children and adolescents. Pediatr Allergy Immunol. 2015;26:551-6.

73. Oba Y, Salzman GA. Cost-effectiveness analysis of omalizumab in adults and adolescents with moderate-to-severe allergic asthma. J Allergy Clin Immunol. 2004;114:265-9.

74. Campbell JD, Spackman DE, Sullivan SD. The costs and consequences of omalizumab in uncontrolled asthma from a USA payer perspective. Allergy. 2010;65:1141-8.

75. Busse W, Buhl R, Fernandez Vidaurre C, Blogg M, Zhu J, Eisner MD, et al. Omalizumab and the risk of malignancy: results from a pooled analysis. J Allergy Clin Immunol. 2012;129:983-9.

76. Lowe PJ, Renard D. Omalizumab decreases IgE production in patients with allergic (lgE-mediated) asthma; PKPD analysis of a biomarker, total IgE. $\mathrm{Br} J$ Clin Pharmacol. 2011;72:306-10.

77. Molimard M, Mala L, Bourdeix I, Le Gros V. Observational study in severe asthmatic patients after discontinuation of omalizumab for good asthma control. Respir Med. 2014;108:571-6.

78. Busse WW, Trzaskoma B, Omachi TA, Canvin J, Rosen K, Chipps BE, et al. Evaluating Xolair persistency of response after long-term therapy (XPORT). Am J Respir Crit Care Med. 2014:189:A6576.

79. Guilbert TW, Morgan WJ, Zeiger RS, Mauger DT, Boehmer SJ, Szefler SJ, et al. Long-term inhaled corticosteroids in preschool children at high risk for asthma. N Engl J Med. 2006;354:1985-97.

80. Akdis CA. Therapies for allergic inflammation: refining strategies to induce tolerance. Nat Med. 2012;18:736-49.

81. National Heart, Lung, and Blood Institute. Expert panel report 3: Guidelines for the diagnosis and management of asthma-full report 2007. Available at: https://www.nhlbi.nih.gov/files/docs/guidelines/ asthgdln.pdf. Accessed 4 Feb 2018.

82. Joint Task Force on Practice Parameters, American Academy of Allergy, Asthma and Immunology, American College of Allergy, Asthma and Immunology, Joint Council of Allergy, Asthma and Immunolgy. Allergen immunotherapy: a practice parameter second update. J Allergy Clin Immunol. 2007;120:S25-85.

83. Zuberbier T, Bachert C, Bousquet PJ, Passalacqua G, Walter Canonica G, Merk $\mathrm{H}$, et al. GA(2) LEN/EAACl pocket guide for allergen-specific immunotherapy for allergic rhinitis and asthma. Allergy. 2010;65:1525-30. 
84. Pajno GB, Bernardini R, Peroni D, Arasi S, Martelli A, Landi M, et al. Clinical practice recommendations for allergen-specific immunotherapy in children: the Italian consensus report. Ital J Pediatr. 2017:43:13.

85. Pitsios C, Demoly P, Bilo MB, Gerth van Wijk R, Pfaar O, Sturm GJ, et al. Clinical contraindications to allergen immunotherapy: an EAACI position paper. Allergy. 2015;70:897-909.

86. Tsabouri S, Mavroudi A, Feketea G, Guibas GV. Subcutaneous and sublingual immunotherapy in allergic asthma in children. Front Pediatr. 2017;5:82.

87. Jutel M, Agache I, Bonini S, Burks AW, Calderon M, Canonica W, et al. International consensus on allergy immunotherapy. J Allergy Clin Immunol. 2015;136:556-68.

88. Hedlin $G$, van Hage M. The role of immunotherapy in the management of childhood asthma. Ther Adv Respir Dis. 2012;6:137-46.

89. Lambert N, Guiddir T, Amat F, Just J. Pre-treatment by omalizumab allows allergen immunotherapy in children and young adults with severe allergic asthma. Pediatr Allergy Immunol. 2014;25:829-32.

90. Kopp MV, Hamelmann E, Zielen S, Kamin W, Bergmann K-C, Sieder C. Combination of omalizumab and specific immunotherapy is superior to immunotherapy in patients with seasonal allergic rhinoconjunctivitis and co-morbid seasonal allergic asthma. Clin Exp Allergy. 2009;39:271-9.

91. Massanari M, Nelson H, Casale T, Busse W, Kianifard F, Geba GP. Effect of pretreatment with omalizumab on the tolerability of specific immunotherapy in allergic asthma. J Allergy Clin Immunol. 2010;125:383-9.

92. Stelmach I, Kaczmarek-Woźniak J, Majak P, Olszowiec-Chlebna M, Jerzynska J. Efficacy and safety of high-doses sublingual immunotherapy in ultra-rush scheme in children allergic to grass pollen. Clin Exp Allergy. 2009;39:401-8.

\section{Submit your next manuscript to BioMed Central and we will help you at every step:}

- We accept pre-submission inquiries

- Our selector tool helps you to find the most relevant journal

- We provide round the clock customer support

- Convenient online submission

- Thorough peer review

- Inclusion in PubMed and all major indexing services

- Maximum visibility for your research

Submit your manuscript at www.biomedcentral.com/submit 